\title{
MARK 16:8 AND PLATO, PROTAGORAS 328D
}

\section{Nicholas Denyer}

What we have of the Gospel of Mark comes to an abrupt halt at 16:8

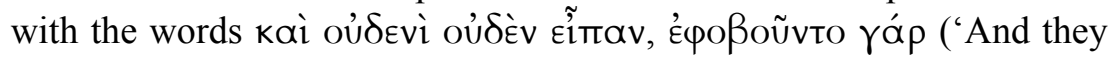
said nothing to anyone, for they were afraid'). Such a cliff-hanger was felt intolerable by some ancients, who composed and transmitted to us various passages that bring the Gospel to a more satisfying close. ${ }^{1}$ Many modern scholars, too, have found it hard to believe that Mark indeed intended his Gospel to end at 16:8. The author of the most recent monograph on the topic lists eighty-nine such scholars, and is himself a ninetieth. ${ }^{2}$

In all the debate about the end of Mark, nobody seems to have drawn attention to Plato, Protagoras 328d. Part of the significance of this passage is that it provides further confirmation, if further

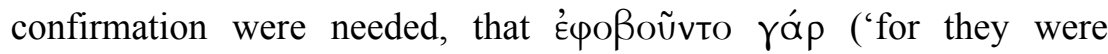
afraid') - a two-word clause, where the second word means 'for' - is an astonishingly abrupt end. But its main significance is this: it provides proof that so astonishingly abrupt an end could well be deliberate. $^{3}$

The context is this: various things, among them the fact that the sons of good fathers are not always good themselves, seem to indicate that virtue is not teachable; Protagoras earns his living by giving lessons in

1 For a succinct description, see B. M. Metzger, A Textual Commentary on the Greek New Testament, 2nd edn (Stuttgart and New York: United Bible Societies, 1994): 102106.

2 N. Clayton Croy, The Mutilation of Mark's Gospel (Nashville: Abingdon, 2003): 174-77.

3 Two other examples of works ending in үá $\rho$ have been discussed in the literature.

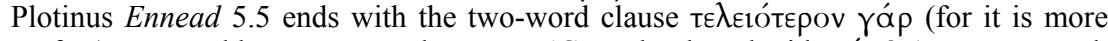
perfect), as noted by P. W. van der Horst, 'Can a book end with үá $\rho$ ? A note on Mark XVI.8' Journal of Theological Studies 23 (1972): 121-24. But evidence from Porphry's Life of Plotinus 8.1-19 suggests that Plotinus often wrote without due care and attention. Musonius Rufus Dissertations 12 ends with the two-word clause

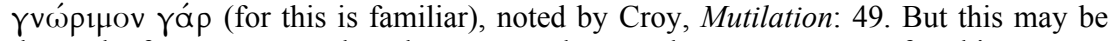
the end of an extract rather than a complete work, as our source for this passage (Stobaeus, Anthology 3.6.23) gives this passage a heading which presents it as only an

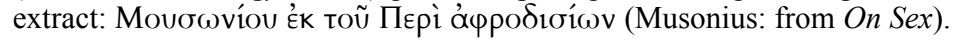


virtue, and has been challenged to show that it is indeed possible to teach people to be good; he attempts to meet this challenge by a rhetorical tour de force; Protagoras' speech is not on the scale of Mark's Gospel (the speech contains around 2,500 words; the Gospel contains around 12,000); it is, nevertheless, a substantial work of literature in its own right; Protagoras brings his speech to an end by turning to talk of two men in the audience who have not, so far at least, come to be as good as their father. The last words of the speech are:

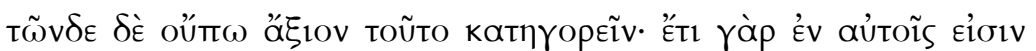

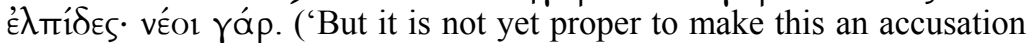
against them; for there is still some hope for them; for they are young.')

Socrates continues by describing the effect on him of this ending:

Having given a virtuoso performance in these terms and at this length, Protagoras stopped speaking. As for me, I was for a long time entranced: I still kept on looking at him, expecting that he would say something, and yearning to hear it. But when I appreciated that he really had stopped, I somehow managed to pull myself together, and looked at Hippocrates and said....

Of course, the mere fact that Plato's Protagoras chooses this way of ending his speech is hardly even evidence that Mark chose the same way of ending his Gospel. It is, however, proof that there is no anachronism whatsoever in the hypothesis that Mark chose precisely such a means of leaving the reader in what is, after all, a proper frame of mind for someone who has just read a gospel: thinking that the story of the risen Christ cannot be over yet, and yearning to hear more. ${ }^{4}$ It was, no doubt, this yearning that generated the various conclusions that we find in manuscripts of the Gospel of Mark.

4 A further example, in which a complete work by a competent writer ends with a two-word clause with rá $\rho$ apparently aims at, and achieves, a modest amount of literary suspense, may well be found in Lucian Courtesans' Conversations 6,

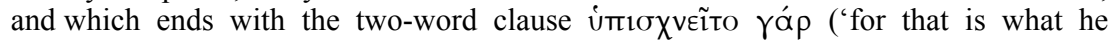
promises'). The speaker is a mother; the addressee is her daughter; the mother, as she has been explaining during the Conversation, is about to start the daughter on a career in prostitution. Translated in full, the final sentence runs: 'Now off you go and have a bath, in case the young man Eucritus comes today; for that is what he promises.' 